\title{
Optimalisasi Pemanfaatan Lahan Pekarangan Pada Kelompok Keswadayaan Masyarakat di Kelurahan Kedungwuluh Kecamatan Purwokerto Barat
}

\author{
Lilis Siti Badriah ${ }^{1 *}$, Dijan Rahajuni ${ }^{1}$, Etik Wukir Tini ${ }^{2}$ \\ ${ }^{1}$ Fakultas Ekonomi dan Bisnis, Universitas Jenderal Soedirman, Purwokerto, Indonesia \\ ${ }^{2}$ Fakultas Pertanian, Universitas Jenderal Soedirman, Purwokerto, Indonesia \\ *Penulis korespondensi, email: lilis.badriah@unsoed.ac.id
}

\section{Submit : \\ 6 Juli 2020 \\ Diterima: \\ 18 Agustus 2020 \\ Terbit: \\ 30 Agustus 2020}

Abstrak. Peningkatan nilai ekonomi lahan pekarangan melalui
pemanfaatannya sudah dilaksanakan oleh masyarakat di
Kelurahan Kedungwuluh tetapi hasilnya belum optimal. Mereka
menginginkan kegiatannya tersebut menjadi lebih produktif, tetapi
terkendala oleh keterbatasan pengetahuan dan keterampilan.
Dalam aspek produksi mereka mengahadapi masalah bagaimana
cara meningkatkan produktivitas lahan pekarangan sedangkan
masalah dalam aspek manajemen adalah bagaimana cara melakukan pembukuan keuangan usaha yang benar. Tujuan pengabdian masyarakat ini, pertama, untuk memberikan solusi dalam meningkatkan produktivitas lahan pekarangan melalui perbaikan metode bercocok tanam sayuran organik dengan teknik vertikultur. Kedua, untuk memberikan solusi dalam aspek manajemen dengan mengadakan penyuluhan, pelatihan, dan pendampingan proses penyusunan pembukuan. Mitra kegiatan adalah kelompok keswadayaan masyarakat di Kelurahan Kedungwuluh Kecamatan Purwokerto Barat, Kabupaten Banyumas. Metode pelaksanaan kegiatan terdiri dari ceramah, praktek/pelatihan, evaluasi, dan pendampingan. Pelaksanaan kegiatan ini telah menunjukkan adanya peningkatan pengetahuan dan keterampilan mitra. Indikator keberhasilan antara lain terlihat dari hasil wawancara dengan kelompok masyarakat yang menunjukkan adanya peningkatan pengetahuan dan keterampilan mereka setelah pemberian penyuluhan dan pelatihan dibandingkan sebelumnya. Keberhasilan juga terlihat dari adanya peningkatan produktivitas lahan dengan indikator jumlah tanaman yang bertahan hidup sampai masa panen lebih banyak jika dibandingkan kondisi sebelumnya. Dengan demikian hasil yang diperoleh saat ini tidak saja dapat digunakan untuk memenuhi kebutuhan konsumsi keluarga, tetapi juga ada sebagian yang dapat dijual sehingga kegiatan ini dapat menghemat pengeluaran dan dapat mendorong peningkatan pendapatan.

Kata Kunci: manajemen pembukuan, usaha produktif, sayuran organik, teknik vertikultur 


\section{PENDAhUluan}

Upaya pemberdayaan masyarakat merupakan tanggung jawab bersama antara pemerintah, perguruan tinggi, perusahaan, dan masyarakat itu sendiri sebagai salah satu cara untuk meningkatkan partisipasi aktif masyarakat dalam proses pembangunan.

Menurut Djohani (2003) dalam Anwas (2014) bahwa pemberdayaan adalah suatu proses untuk memberikan daya/kekuasaan (power) kepada pihak yang lemah (powerless), dan mengurangi kekuasaan (disempowered) kepada pihak yang terlalu berkuasa (powerful) sehingga terjadi keseimbangan. Menurut Usman (2003) dalam proses pemberdayaan diperlukan sinergi dari berbagai pihak seperti pemerintah daerah, lembaga social, dan perguruan tinggi dan atau pemerhati sebagai fasilitator.

Partisipasi dan pemberdayaan merupakan dua buah konsep yang saling berkaitan. Untuk menumbuhkan partisipasi masyarakat diperlukan upaya pemberdayaan. Partisipasi yang lemah dapat disebabkan oleh kekurangan kapasitas dalam masyarakat tersebut, sehingga peningkatan kapasitas perlu dilakukan (Rokhman, 2008; Nugroho, 2009).

Oleh karena itu, proses pemberdayaan yang dilaksanakan melalui berbagai program yang dirancang sesuai dengan potensi dan preferensi masyarakat dapat menjadi salah satu cara untuk dapat meningkatkan kapasitas diri masyarakat dan memperkuat partisipasi mereka dalam mewujudkan kemandiriannya.

Program KOTAKU adalah salah satu program pemerintah untuk menangani pemukiman kumuh di wilayah perkotaan, dimana wilayah kumuh identik dengan kemiskinan. Walaupun program PNPM sudah berakhir, tetapi karena dana pinjaman yang ada di masyarakat yang dikelola oleh Kelompok Swadaya Masyarakat Ekonomi masih terus bergulir, maka Rahajuni, dkk (2018) melakukan upaya mengkolaborasikan antara program PNPM dengan program KOTAKU dalam suatu penelitian mengenai model pengelolaan KSM pada program pemberdayaan masyarakat KOTAKU. Salah satu sampel wilayah penelitian tersebut adalah Kelurahan Kedungwuluh Kecamatan Purwokerto Barat Kabupaten Banyumas.

Program pengabdian ini dilaksanakan Berbasis pada hasil penelitian Rahajuni, dkk (2018) tersebut dalam rangka mengembangkan kapasitas diri masyarakat di Kelurahan Kedungwuluh Kecamatan Purwokerto Barat sesuai dengan preferensi mereka untuk mampu mengembangkan kegiatan pemanfaatan lahan pekarangan yang sudah berjalan saat ini menjadi kegiatan yang lebih produktif. Dengan demikian diharapkan kegiatannya tersebut mampu meningkatkan nilai ekonomi pekarangan sehingga dapat meningkatkan pendapatan mereka.

Upaya pengelolaan dan pemanfaatan lahan di Kelurahan Kedungwuluh dilakukan secara berkelompok. Mereka berkelompok sesuai dengan kelompok warga dalam satu RT yang saat ini sudah melakukan pemanfaatan lahan pekarangan dan memiliki antusiasme yang besar untuk mengoptimalkan nilai ekonomi dari lahan pekarangannya tersebut.

Pemanfaatan lahan yang sudah berjalan saat ini antara lain pada lahan sepanjang jalan aliran irigasi di RT 6 RW 7 yang beranggotakan 10 orang, pada lahan pekarangan warga di RT 5 RW 8 beranggotakan 16 orang, dan pada lahan pekarangan warga yang berada di RT 2 RW 2 beranggotakan 9 orang. Pemberdayaan masyarakat untuk membuat lingkungan tanpa kumuh dilakukan dengan cara memanfaatkan lahan pekarangan yang ada di lingkungan mereka. 
Hasil penelitian Rahajuni, dkk (2018) menunjukkan bahwa lingkungan menjadi bersih dan indah, hasil yang diperoleh sudah dapat dinikmati anggota kelompok tetapi masih bersifat subsisten. Artinya, hasil pemanfaatan pekarangan tersebut baru dapat digunakan untuk keperluan konsumsi anggota kelompok saja karena pengelolaan tanaman masih bersifat sangat sederhana sehingga hasil panen yang didapat masih terbatas dan dampak ekonominya masih belum signifikan, karena mereka pun belum memiliki kemampuan untuk melakukan pencatatan pembukuan mengenai pengelolaan kegiatan tersebut

Adapun potensi lingkungan cukup mendukung, karena dekat dengan aliran sungai yang dapat menjadi sumber pengairan dan mayoritas rumah anggota memiliki lahan pekarangan walaupun tidak terlalu luas. Disamping itu, potensi pasar cukup luas karena lokasi di wilayah perkotaan dekat dengan pasar, baik pasar tradisional maupun pasar modern, sehingga apabila jumlah produk yang dihasilkan relatif besar dengan kualitas yang lebih baik, maka akses pasar tidak saja hanya ke pasar tradisional, tetapi juga bisa akses ke pasar modern.

Apabila melihat kondisi masyarakat yang antusias dalam melakukan kegiatan pemanfaatan lahan pekarangan dan potensi lingkungan yang mendukung serta pasar yang potensial, maka tim pengusul pengabdian kepada masyarakat menganggap penting untuk menindaklanjuti hasil penelitian Rahajuni, dkk (2018) dengan program yang diharapkan dapat lebih meningkatkan nilai ekonomi dari pemanfaatan lahan pekarangan tersebut. Melalui pengelolaan yang lebih baik, baik dari sisi budidaya tanamannya maupun dari sisi pembukuan kelompoknya diharapkan hasil yang diperoleh dapat lebih baik, baik dari segi kualitas maupun kuantitas. Dengan demikian dapat diharapkan hasil yang diperoleh tidak hanya sekedar untuk keperluan subsisten, tetapi juga dapat dijual yang pada akhirnya dapat meningkatkan pendapatan kelompok dan keluarga.

Sasaran mitra dari program pengabdian ini adalah kelompok masyarakat yang ada di Kelurahan Kedungwuluh bagian utara (RT 6 RW 7), bagian tengah (RT 5 RW 8), dan bagian Selatan (RT2 RW 2) yang telah melakukan pemanfaatan lahan pekarangannya, tetapi masih menghadapi kendala untuk mengembangkan kegiatannya tersebut untuk menjadi kegiatan yang bersifat lebih produktif dan memberikan nilai ekonomi yang lebih tinggi. Berdasarkan hasil wawancara dengan mitra, kendala yang mereka hadapi dapat dilihat dari aspek produksi dan aspek manajemen. Kendala yang dihadapi tersebut antara lain lebih banyak terkait dengan tingkat pendidikan masyarakat yang mayoritas berpendidikan SMP ke bawah sehingga untuk mampu mengembangkan kapasitas diri mereka perlu adanya stimulus dan motivasi dari pihak eksternal melalui pemberian fasilitasi yang sesuai dengan preferensi mereka.

Dari aspek produksi, kendala yang dihadapi adalah bagaimana mereka mampu berproduksi secara lebih efisien, mampu meningkatkan jumlah produksi lebih banyak dengan kualitas yang lebih baik sehingga menjadi produk yang layak jual. Ada keinginan dari mereka untuk dapat mengembangkan kegiatan bercocok tanam tersebut menjadi kegiatan usaha produktif, mengingat potensi pasar yang ada relatif besar karena sayuran merupakan bagian pangan yang dibutuhkan masyarakat.

Dari aspek manajemen, mereka masih memiliki keterbatasan dalam pembukuan keuangan. Mereka masih belum mampu membuat pembukuan keuangannya sehingga mereka belum bisa menghitung untung rugi dari 
kegiatannya tersebut secara akurat. Padahal pembukuan yang sistematis menjadi salah satu sarana penting sebagai dasar untuk membuat perencanaan usaha dan dari pencatatan yang baik dapat terlihat kinerja usaha yang menjadi salah satu tolok ukur keberhasilan usaha.

Melihat permasalahan yang dihadapi oleh mitra tersebut di atas, maka Tim Pengabdian Kepada Masyarakat sepakat bersama-sama dengan mitra untuk menetapkan persoalan prioritas pada aspek produksi dan aspek manajemen tersebut.

Oleh karena itu, tujuan pengabdian masyarakat ini adalah untuk memberikan solusi dalam meningkatkan produktivitas lahan pekarangan melalui perbaikan metode bercocok tanam sayuran organik dengan teknik vertikultur. Disamping itu, tujuan yang lainnya adalah untuk memberikan solusi dalam aspek manajemen dengan mengadakan penyuluhan, pelatihan, dan pendampingan proses penyusunan pembukuan.

\section{METODE}

Sebagaimana telah diuraikan pada bagian pendahuluan bahwa mitra memiliki kemauan yang kuat untuk mengembangkan kegiatan pemanfaatan lahan pekarangan yang sudah berjalan saat ini, tidak hanya produksi untuk memenuhi kebutuhan subsisten saja, tetapi juga ingin menjadikannya kegiatan usaha produktif yang dapat memberikan nilai ekonomi yang lebih baik. Tetapi dalam pelaksanaannya mereka masih memiliki keterbatasan, baik dalam aspek produksi maupun aspek manajemen. Oleh karena itu, tim pengabdian kepada masyarakat memberikan solusi atas permasalahan yang dihadapi, sebagai berikut:

Solusi terkait aspek produksi adalah perbaikan dalam metode/teknik bertanam dan teknik pemeliharaannya. Selama ini mereka bercocok tanam hanya dengan cara yang relatif sederhana, baik dari teknik, sarana tanam, maupun proses pemeliharaannya. Oleh karena itu, kegiatan pengabdian kepada masyarakat ini berusaha untuk meningkatkan pengetahuan dan keterampilan mitra dalam bercocok tanam dengan melakukan budidaya sayuran organik dengan sistem/teknik vertikultur. Kelebihan sayuran organik ini disamping lebih higienis, juga nilai jualnya lebih tinggi.

Sistem vertikultur merupakan sistem pertanian yang dilakukan secara vertikal (bertingkat). Sistem vertikultur merupakan solusi bagi kepemilikan lahan yang terbatas untuk bercocok tanam.

Kelebihan sistem pertanian vertikultur, yaitu: (1) Penggunaan lahan menjadi lebih efisien. (2) Pemakaian pupuk dan pestisida lebih hemat. (3) Tanaman dapat diletakkan dalam wadah tertentu sehingga dapat dengan mudah untuk dipindahkan. (4) Pemeliharaan tanaman lebih mudah. Terdapat banyak Jenis tanaman yang dapat ditanam dengan sistem ini, antara lain: a) tanaman sayur semusim (sawi,selada, kubis, wortel, tomat, terong, cabai dan lainlainnya), b) tanaman bunga dan tanaman, c) tanaman obat-obatan yang sekulen. Disamping itu, dari sisi estetika, lingkungan akan tampak lebih indah dan rapi.

Pengenalan teknik vertikultur didahului dengan kegiatan penyuluhan dan dilanjutkan dengan pembuatan demplot. Luaran yang diharapkan dari solusi terhadap aspek produksi ini adalah hasil panen tanaman sayur organik dalam jumlah yang lebih banyak dan kualitas yang lebih baik. Indikator yang digunakan adalah bahwa lebih dari $50 \%$ dari jumlah bibit yang ditanam dapat bertahan hidup sampai masa panen 
dengan kualitas yang lebih baik (daun tanaman hijau dan segar).

Dari sisi manajemen, mereka masih memiliki keterbatasan kemampuan dalam menyusun pembukuan keuangan. Alternatif solusi yang dilakukan oleh tim pengusul adalah dengan mengadakan pelatihan dan pendampingan mengenai proses pembukuan yang dapat dijadikan sarana untuk evaluasi kinerja usaha. Luaran yang diharapkan dari solusi terhadap aspek manajemen ini adalah pengetahuan dan kemampuan mitra dalam membuat pembukuan meningkat. Indikator yang digunakan adalah tingkat kesalahan mitra dalam membuat laporan pembukuan, < $25 \%$.

Metode pelaksanaan kegiatan pengabdian kepada masyarakat secara garis besarnya terdiri dari metode ceramah melalui penyuluhan sebagai sarana untuk memberikan bekal ilmu pengetahuan dan perluasan wawasan, metode praktek/pelatihan sebagai sarana tindak nyata dari pengetahuan yang didapat secara teori pada saat penyuluhan, dan metode evaluasi dan pendampingan, sebagai sarana untuk koreksi, pembimbingan, pengarahan, dan pemberian motivasi bagi mitra.

Adapun langkah-langkah solusi yang ditempuh adalah sebagai berikut:

Aspek produksi:

a. Mengadakan wawancara sebelum penyuluhan dilakukan untuk mengetahui sejauh mana pemahaman dan wawasan mitra mengenai pemanfaatan lahan pekarangan dan teknik bertanam dengan vertikultur.

b. Mengadakan penyuluhan mengenai pemanfaatan lahan pekarangan

c. Mengadakan wawancara kembali setelah penyuluhan lalu membandingkan hasil wawanacara sebelum dan sesudah penyuluhan untuk mengukur keberhasilan penyuluhan dalam meningkatkan pengetahuan mitra.

d. Melakukan praktek melalui
pelatihan dengan pembuatan
demplot.

e. Melakukan evaluasi dan pendampingan kegiatan.

Aspek Manajemen:

a. Mengadakan wawancara sebelum penyuluhan dilakukan untuk mengetahui sejauh mana pemahaman dan wawasan mitra mengenai pentingnya pembukuan, dan tata cara membuat pembukuan.

b. Mengadakan penyuluhan mengenai pembukuan.

C. Mengadakan wawancara kembali setelah penyuluhan lalu membandingkan hasil wawanacara sebelum dan sesudah penyuluhan untuk mengukur keberhasilan penyuluhan dalam meningkatkan pengetahuan mitra.

d. Melakukan praktek membuat pembukuan dan sekaligus bagaimana cara menilai kinerja berdasarkan laporan pembukuan tersebut.

e. Melakukan evaluasi dan pendampingan kegiatan.

Kegiatan pengabdian masyarakat ini merupakan upaya membangkitkan partisipasi masyarakat dalam proses pemberdayaan diri mereka. Partisipasi mitra dalam program kemitraan masyarakat ini adalah dengan cara (1) menyediakan berbagai informasi dan data yang diperlukan, (2) menyediakan lahan pekarangan yang dapat digunakan untuk melakukan kegiatan, (3) menyediakan waktu luang untuk mengikuti penyuluhan dan pelatihan secara disiplin, (4) menyediakan alatalat yang diperlukan, yang mereka miliki, (5) melakukan budidaya tanaman sayuran organik dengan teknik vertikultur.

Untuk setiap tahapan kegiatan, dilakukan evaluasi, antara lain: 
a. Untuk kegiatan penyuluhan dapat dilihat perbandingan kondisi pemahaman dan kemampuan masyarakat antara sebelum dan setelah penyuluhan dilakukan.

b. Untuk kegiatan praktek bercocok tanam sayuran organik dengan teknik vertikultur, evaluasi kegiatan dilakukan dengan melihat berapa banyak bibit tanaman yang bertahan hidup sampai masa panen dan berapa banyak yang mati. Jika proporsi bibit tanaman yang bertahan hidup lebih dari $50 \%$ menunjukkan adanya peningkatan dalam keterampilan mitra.

c. Untuk kegiatan pelatihan pembuatan pembukuan, evaluasi dilakukan dengan melihat ketepatan mereka dalam menyusun pembukuan tersebut.

Selama program kegiatan pengabdian kepada masyarakat terus dilakukan pendampingan untuk memberikan evaluasi, bimbingan, dan arahan terhadap mitra.

\section{HASIL DAN PEMBAHASAN}

Pelaksanaan kegiatan pengabdian ini dilakukan melalui beberapa tahapan. Berikut adalah uraian mengenai pelaksanaan pada masing-masing tahapan.

\section{Sosialisasi Rencana Kegiatan}

Sosialisasi rencana kegiatan yang akan dilaksanakan merupakan langkah awal yang dilakukan Tim Pengabdi untuk memberikan gambaran komprehensif kepada masyarakat, termasuk mitra sasaran mengenai rangkaian kegiatan selama program pengabdian masyarakat dilakukan.

\section{Penyuluhan terkait aspek produksi}

Penyuluhan aspek produksi bertujuan untuk meningkatkan pengetahuan dan wawasan mitra dalam kemampuan berproduksi yang efektif dan efisien. Menurut pertimbangan
Tim Pengabdi, karena lahan pekarangan yang dimiliki masyarakat relatif terbatas, maka untuk optimalisasi nilai ekonomi pekarangan dipilih budidaya tanaman melalui teknik vertikultur..

\section{Penyuluhan terkait aspek manajemen}

Penyuluhan aspek manajemen bertujuan untuk meningkatkan pengetahuan dan wawasan mitra dalam kemampuan menyusun pembukuan usaha. Hal ini dianggap sebagai faktor esensial dalam suatu kegiatan produktif untuk mampu mengetahui secara akurat cashflow finansial kegiatan yang dilakukan.

\section{Praktek Pembuatan demplot budidaya tanaman secara vertikultur}

Untuk lebih memantapkan pemahaman mereka atas materi penyuluhan yang telah dilaksanakan, maka selanjutnya dilakukan pembuatan demplot budidaya tanaman secara teknik vertikultur. Sebelum pembuatan demplot dilaksanakan, terlebih dahulu dilakukan survey lapangan oleh Tim Pengabdi untuk memastikan kondisi dan tempat yang tepat untuk dijadikan lokasi pembuatan demplot. Berdasarkan hasil survey tersebut akhirnya disepakati bahwa demplot vertikultur hanya dilakukan di dua tempat, yaitu RT 2 RW 2 dan RT 5 RW 8 , mengingat lahan pekarangan yang mitra miliki relatif terbatas. Sedangkan untuk RT 6 RW 7, pembuatan demplot dilakukan secara teknik non-vertikultur mengingat luas lahan yang relatif panjang di wilayah aliran sungai.

Dalam mendukung pembuatan demplot, tim Pengabdi memberikan bantuan berupa rak vertikultur, media tanam, pupuk, dan bibit tanaman. Bibit tanaman yang dibudidayakan 
yaitu sawi, pokcoy, kangkung, tomat, cabai, terong. Selain itu juga diberikan beberapa peralatan untuk bercocok tanam.

Dalam prakteknya, pembuatan demplot dilakukan secara 2 type. Yang pertama demplot dengan treatment, yaitu bahwa dalam pembuatan demplot tersebut media tanam sudah disediakan langsung oleh Tim Pengabdi dalam kondisi siap tanam dan yang kedua demplot tanpa treatment, yaitu bahwa proses budidaya dilakukan secara mandiri oleh masyarakat. Tujuannya, untuk dapat melihat perbandingan keduanya dan kemudian dilakukan evaluasi.

\section{Praktek penyusunan laporan keuangan}

Penyusunan laporan keuangan dilakukan dengan menunjukkan cara pembuatan buku pembantu, seperti buku pembelian bahan dan buku penjualan. Lalu penyusunan jurnal buku besar. Berdasarkan pembukuan tersebut dapat diketahui biaya produksi yang diperlukan dalam satu masa panen sehingga dapat dijadikan acuan sebagai dasar penentuan harga jual produk.

\section{Evaluasi kegiatan}

Evaluasi efektivitas dari kegiatan praktek/pelatihan, dari hasil demplot vertikultur terlihat bahwa produktivitas lahan yang mendapat treatment lebih tinggi daripada yang tidak mendapatkan treatment, dengan indikator jumlah tanaman yang bertahan sampai akhir masa panen masing-masing sebesar $80 \%$ dan $70 \%$. Kualitas tanaman yang dihasilkan pun lebih segar. Kondisi ini memberikan rasa optimistis bahwa peningkatan nilai ekonomi pekarangan sangat dimungkinkan tercapai mengingat dari hasil panen demplot dapat diperoleh produk tidak saja dapat digunakan untuk memenuhi konsumsi anggota kelompok tetapi juga dapat dijual ke tetangga sekitar. Sehingga dengan demikian, kegiatan ini telah mampu membuat penghematan pengeluaran keluarga dan dapat mendorong peningkatan pendapatan. Hasil pelaksanaan kegiatan dapat terlihat pada Gambar 1 dan 2.

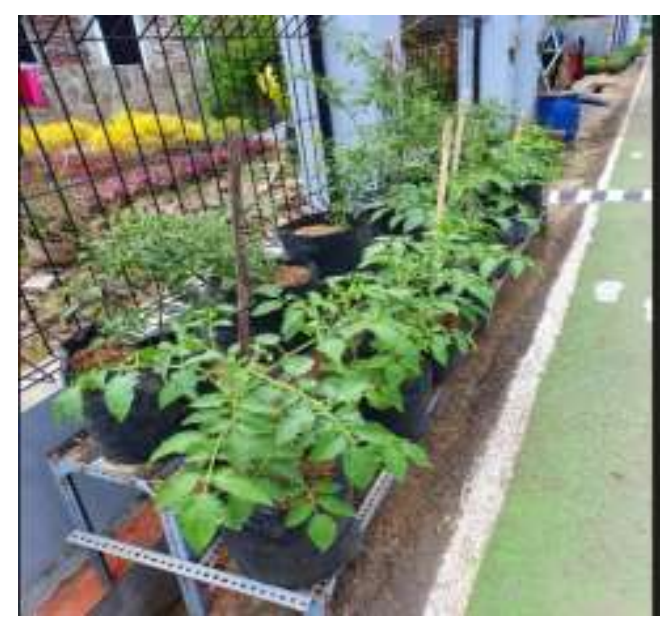

Gambar 1. Demplot Vertikultur

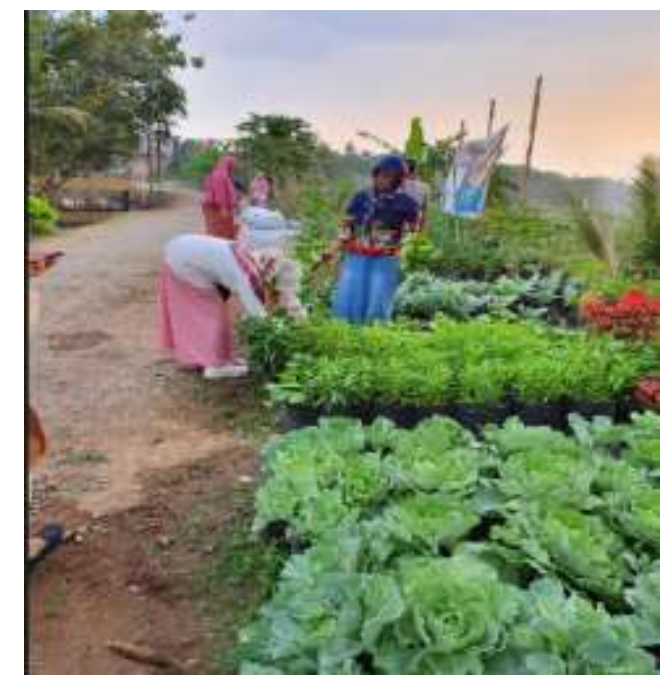

Gambar 2. Demplot Non-Vertikultur

Praktek pembuatan pembukuan telah menunjukkan keberhasilan yang terlihat dari indikator bahwa mitra telah dapat membuat pembukuan sebagaimana seharusnya.

\section{KESIMPULAN}




\begin{abstract}
Program pengabdian kepada masyarakat di Kelurahan Kedungwuluh Kecamatan Purwokerto Barat Kabupaten Banyumas telah menunjukkan hasil sesuai yang diharapkan yaitu adanya peningkatan pengetahuan dan keterampilan mereka untuk dapat meningkatkan produktivitas lahan dan juga dalam manajemen pembukuannya. Disamping itu juga adanya peningkatan nilai ekonomi masyarakat dari pemanfaatan lahan pekarangan yang dilakukannya, baik berupa penghematan pengeluaran keluarga maupun peningkatan pendapatan.
\end{abstract}

\section{UCAPAN TERIMAKASIH}

Ucapan terimakasih disampaikan kepada Kementerian Ristek Dikti sebagai penyedia dana bagi pelaksanaan kegiatan ini, Rektor Unsoed, Dekan FEB Unsoed, dan Ketua LPPM Unsoed serta kepada Kepala Kelurahan Kedungwuluh dan Masyarakatnya yang telah berpartisipasi aktif mendukung terlaksananya kegiatan Pengabdian Kepada Masyarakat ini.

\section{DAFTAR PUSTAKA}

Anwas, O. M. 2014. Pemberdayaan Masyarakat di Era Global. Bandung: Alfabeta.

Ariningsih, E dan H.P.S Rachman. 2008. Strategi Peningkatan Ketahanan Pangan Rumah Tangga Rawan Pangan. Analisis Kebijakan Pertanian, 6(3):239255.

Fetterman, David and Wandersman, Abraham 2007. Empowerment Evaluation: Yesterday, Today, and Tomorrow. American Journal of Evaluation 2007;28; 179.

Nugroho, A. E. 2009. The Pro-Poor Policy of Microfinance in Indonesia, Gadjah Mada International Journal of
Business, Vol. 11. No. 3, September-December 2009. Pp317-340.

Rahajuni, D dan Badriah, L. S. 2011. Pengembangan Model Pemberdayaan Masyarakat Miskin Dalam Rangka Pengentasan Kemiskinan Di Kabupaten Banyumas (Studi Kasus Pada PNPM Mandiri Perkotaaan). Prosiding Seminar Nasional: Pengembangan Sumber Daya Pedesaan dan Kearifan Lokal Berkelanjutan, Purwokerto, 23-24 Nopember 2011. Lembaga Penelitian dan Pengabdian Kepada Masyarakat Universitas Jenderal Soedirman, Purwokerto.

Rahajuni, D, Suprapto, Lestari, S, dan Badriah, L.S. 2018. Model Pengelolaan Kelompok Swadaya Masyarakat (KSM) Ekonomi Pada Program Pemberdayaan Masyarakat Kota Tanpa Kumuh (Kotaku) Studi Kasus Di Kabupaten Banyumas. (Laporan penelitian). Jurnal Ekuitas: Submitted.

Rokhman, N. 2008. Dampak Pemberdayaan UMKM Melalui Program Pendampingan (Studi Kasus Pendampingan di Sentra Aluminium Yogyakarta), Telaah Bisnis, Vol. 9 (2): 45-165.

Suharto, E. 2005. Membangun Masyarakat Memberdayakan Rakyat. Bandung:Refika Aditama.

Usman, S. 2003. Pembangunan dan Pemberdayaan Masyarakat. Pustaka Pelajar. Yogyakarta. 